\section{Spatial economic evolution of the airport-centric developments of Cape Town and OR Tambo international airports in South Africa}

\author{
Masilonyane Mokhele
}

http://dx.doi.org/10.18820/2415-0495/trp70i1.3

Peer reviewed and revised February 2017

\begin{abstract}
Among other categories of literature on the relationship between airports and land use, planning models of airport-led development are becoming bandwagons hailed by the proponents as key to the future of cities. While acknowledging the insights of literature, it is argued that concerted focus is required on analysing the spatial economic evolution of airport-centric developments. The aim of this article is to explore the evolution of the airport-centric developments of Cape Town and OR Tambo international airports in South Africa. Through the use of topographical maps, aerial photography and historical literature, the evolution is traced over six decades, namely the 1950s, 1960s, 1970s, 1980s, 1990s and 2000s. The article discovers that, despite policy and planning efforts, airport-centric developments occur over fairly long time frames. It is also imperative that the planning of airports and surrounds be informed by the integration of, among others, spatial, economic, and transportation planning at different scales.
\end{abstract}

Keywords: Airport-centric development, Cape Town International Airport, evolution, OR Tambo International Airport, South Africa

\section{RUIMTELIKE EKONOMIESE EVOLUSIE VAN DIE LUGHAWE-SENTRIESE ONTWIKKELINGE VAN KAAPSTAD- EN OR TAMBO-LUGHAWENS IN SUID-AFRIKA}

Literatuur oor die verhouding tussen lughawens en grondgebruik toon dat beplanningsmodelle oor die ontwikkeling van lughawens deur die voorstaanders van hierdie ontwikkelingsmodelle tans beskou word as die sleutel tot die toekoms van stede. Terwyl die literatuur erken word, word daar aangevoer dat daadwerklik gefokus moet word op die ontleding van die ruimtelike ekonomiese ontwikkeling van die lughawe-sentriese ontwikkelings. Die doel van hierdie artikel is om die evolusie van die lughawe-sentriese ontwikkeling van Kaapstad- en die OR Tambo-lughawes in Suid-Afrika te verken. Deur die gebruik van topografiese kaarte, lugfoto's en historiese literatuur, is die evolusie nagespoor vir ses dekades, naamlik die 1950's, 1960's, 1970's, 1980's, 1990's en 2000's. Die ondersoek toon dat, ten spyte van beleid en beplanningspogings, lughawe-sentriese ontwikkeling oor taamlike lang tydsraamwerke voorkom. Dit is ook noodsaaklik dat die beplanning van lughawens en omgewing in kennis gestel word deur die integrasie van, onder andere, ruimtelike, ekonomiese en vervoer-beplanning op verskillende skale.

Sleutelwoorde: Ewolusie, lughawe-sentriese ontwikkeling, Kaapstad internasionale lughawe, OR Tambo internasionale lughawe, Suid-Afrika

\section{PHETOHO YA MORUO WA SEBAKA SE MABAKI LE MAEMAFOFANE A MATJHABATJHABA A CAPE TOWN LE OR TAMBO AFRIKA BORWA}

Ka hara dikarolo tse ding tsa dingolwa tse mabapi le dikamano pakeng tsa boemafofane le tshebediso ya lefatshe; dimodele tsa ditlhophiso tse itshetlehileng hodima ntshetsopele ya boemafofane, di ntse di tuma ka lebaka la batshehetsi ba ka sehloohong bokamosong ba ditoropo. Ha ho ntse ho anamelwa dintlha tsa dingolwa, ho ngangisanwa ka hore tsepamiso e hlophisitsweng ya maikutlo e a hlokahala bakeng sa ho lekola phetoho ntshetsopeleng ya moruo wa boemafofane bo sebakeng se bulehileng. Sepheo sa atikele ena ke ho lekola phetoho ntshetsopeleng ya maemafofane a Cape Town matjhbatjhaba a OR Tambo Afrika Borwa. Ka tshebediso ya dimmapa tse bontshang sebopeho sa dinoka le dithaba (topographical maps), difoto tse nkuwang o le sepakapakeng (aerial photography) le dingolwa tsa histori/nalane, phetoho e hatisitsweng nakong ya dilemo tse fetang mashome a tsheletseng,e bitswang 1950s, 1960s, 1970s, 1980s, 1990s le 2000s. Atikele ena e fumane hore ntle le molawana le matsapa a ditlhophiso, ntshetsopeleng ya boemafofane bo bohareng e etsahala ka mora nako e telele. Hape ho bohlokwa hore ditlhophiso tsa boemafofane le tse bo potapotileng di etswe tlasa nyalano e, pakeng tsa; sepakapaka, moruo le ditlhophiso tsa transporoto mekgahlelong e sa tshwaneng.

\section{INTRODUCTION}

Across the world, normative planning models of airport-led development are becoming bandwagons hailed by the proponents as key to the future of cities. Notwithstanding the popularity of various models overviewed in Section 2 of this article, there is a lack of literature that analyses the spatial economic evolution of development on airports and surrounds. Such literature is necessary towards, at least in part, contributing to a better understanding of the driving forces of development on airport environs, and ultimately ensuring that planning initiatives on and around airports are appropriately directed. To draw lessons that could be useful for the planning of other airports and surrounds, this article aims to analyse the evolution of the spatial form of the environs of Cape Town and OR Tambo international airports in South Africa.

\section{THE DEVELOPMENT OF AIRPORTS}

The proposals of the ideal spatial form of airports and surrounds are no new phenomena. Though it is difficult to pinpoint the foundations of such proposals, Meier (1974) had detailed thoughts through the notion of airportbased metropolitan central districts, which develop to facilitate intermetropolitan exchange of freight and passengers. The space requirements for movement by air, together with 
the effects of aircraft noise, force the terminal for passengers and high-valued shipments to peripheral sites within a given city. In those locations, hotels, conference facilities, communication facilities and recreational services concentrate to handle the requirements of interfaces between producers and suppliers, parent firms and their subsidiaries, marketers and their distributors, consulting firms and their clients, and so on. Activities assumed to be attracted to such airport-based metropolitan central districts are mainly express transshipment (Meier, 1974: 289-299).

Numerous terms and models are associated with the ideal land-use composition and spatial form of economic activities that locate on and around airports, which, as noted by Schlaack (2010: 115), are promoted by airport authorities, developers and governments as economically and physically integrated initiatives of the airport and urban development. The concepts include airport city (Conway, 1993; Kasarda, 2009), aerotropolis (Kasarda, 2009; Kasarda \& Lindsay, 2011), airport region (Schlaack, 2010: 116), airfront (Blanton, 2004), global transpark (Kasarda, 1998; Sit, 2004), airport corridor (Schaafsma, 2003, cited in Schlaack, 2010: 114), airea (Schlaack, 2010), decoplex (Conway, 1993), aircity, aeropolis, aeropark, aviopolis, avioport, flight forum, sky city, airpark, aero city, and aeroscape. Among the aforementioned, airport city and aerotropolis can be distinguished as the most dominant in the literature and in practice. Airport city is used worldwide to refer to the growth of aviation and non-aviation activities on and around airports (Walker \& Stevens, 2008: 1), due to their dependence on airports. According to Kasarda (2009), as more firms are attracted to airport cities and along the transportation infrastructure linking such developments, a new urban form emerges. This urban form is referred to as aerotropolis, consisting of developments that could extend up to approximately thirty kilometres from airports (see, for instance, Kasarda \& Lindsay, 2011).
The aerotropolis tag is continuously applied to a diversity of airport environs, planned and unplanned (Freestone \& Barker, 2011: 268).

South Africa is not spared in the hype of airport-led development. For instance, the industrial areas around OR Tambo International Airport (ORTIA) are claimed to be Africa's first aerotropolis (see, for instance, Ekurhuleni Municipality, 2013; 2015). In Cape Town, the airport authority (Airports Company South Africa) and other stakeholders are working on an aerotropolis programme centred on Cape Town International Airport (CTIA) (ACSA, 2015: 76), so as to capture the airport's development benefits for the broader metropolitan area. The development springing up at King Shaka International Airport (KSIA) is branded and marketed as KwaZulu-Natal Aerotropolis or Durban Aerotropolis (see, for instance, ACSA, 2015: 78). For a long time, the City of Johannesburg municipality has faced a difficulty in spatially and economically integrating Lanseria International Airport into the broader Johannesburg, and there have been various efforts to promote development around Lanseria (Klug, Rubin \& Todes, 2014: 430). One of the attempts is known as Cradle City, which the proponents say would incorporate the best elements of the so-called aerocities (Eicker, 2009). Mangaung municipality intends to develop approximately 2,000 hectares of vacant municipal land, in the vicinity of Bram Fischer International Airport, into an aerotropolis (see, for example, Broumels, 2014: 108).

\section{CAPE TOWN AND OR TAMBO AIRPORT-CENTRIC DEVELOPMENTS}

Amidst the different terms and models noted in Section 2, this article uses

\footnotetext{
1 The word vicinity is used here to refer to land that is beyond the premises of Bram Fischer Airport. Although there are advanced development initiatives on the premises of Bram Fischer Airport, they are not part of the aerotropolis initiative of the municipality due to, among others, institutional factors. However, the paper does not go into those complexities. (This information is based on the author's long term involvement in the planning of Bram Fischer's landside. See Mokhele, 2016: 18; 113).
}

the term 'airport-centric development' to refer to a group of 'airport-centric firms' (for a lengthy discussion, see Mokhele, 2016: 7-8). These are firms that are located around the airport, that is, at areas in the geographical proximity of (and contiguous with) the airport, but outside the airport land; on the landside, that is, on the airport's land, but not within the terminals, and within the airport's terminal. In light of the definition above, the current section describes the landuse composition and form of the OR Tambo and Cape Town airport-centric developments relative to other areas in the respective municipal areas of Ekurhuleni and City of Cape Town. It goes without saying that, before tracing the evolution in Section 5, it is imperative to describe the current picture of the cases studied.

In 2014, 1,629 firms were recorded at the OR Tambo airport-centric development (Mokhele, 2016: 185). The OR Tambo airport-centric firms are predominantly located at the areas of Isando, Jet Park, Spartan, Meadowdale, Elandsfontein and Pomona, which are contiguous with the airport, as well as on the airport's landside (see Table 1 and Figure 1). Reflecting the heterogeneity of OR Tambo airport-centric development, Table 1 shows that the development accommodates firms in 17 sections of Statistics South Africa's (2012) standard industrial classification of economic activities (SIC). Notably, ORTIA and its environs represent one of the significant concentrations of industrial activity in the Ekurhuleni municipality. Other main concentrations of industrial activity in the municipality are in Boksburg, Germiston, Wadeville and Alberton.

Like ORTIA, CTIA is surrounded by a diverse concentration of economic activities, though not covering the land area to the extent of ORTIA and surrounds. The majority of firms accommodating various activities are located at the areas of Airport Industria and Airport City, which are contiguous with CTIA, as well as on the airport's landside and terminals (refer to Figure 2). In 2014, 461 firms, spanning 12 Statistics South Africa's (2012) SIC sections, were recorded at the Cape Town airport-centric development 
Table 1: $\quad$ Mix of OR Tambo airport-centric development

\begin{tabular}{|c|c|c|c|c|c|c|}
\hline & \multicolumn{3}{|c|}{ Level of analysis } & \multirow[b]{2}{*}{ Total } \\
\hline & & & $\begin{array}{l}\text { Around } \\
\text { ORTIA }\end{array}$ & $\begin{array}{l}\text { ORTIA } \\
\text { landside }\end{array}$ & $\begin{array}{c}\text { ORTIA } \\
\text { terminals }\end{array}$ & \\
\hline \multirow{34}{*}{$\begin{array}{l}\text { 을 } \\
\dot{D} \\
\infty \\
\infty \\
\frac{U}{\omega}\end{array}$} & \multirow{2}{*}{ Manufacturing } & Count & 347 & 1 & 0 & 348 \\
\hline & & $\%$ of total & $21.3 \%$ & $0.1 \%$ & $0.0 \%$ & $21.4 \%$ \\
\hline & \multirow{2}{*}{ Electricity, gas, steam and air-conditioning supply } & Count & 1 & 0 & 0 & 1 \\
\hline & & $\%$ of total & $0.1 \%$ & $0.0 \%$ & $0.0 \%$ & $0.1 \%$ \\
\hline & \multirow{2}{*}{$\begin{array}{l}\text { Water supply, sewerage, waste management and } \\
\text { remediation activities }\end{array}$} & Count & 4 & 0 & 0 & 4 \\
\hline & & $\%$ of total & $0.2 \%$ & $0.0 \%$ & $0.0 \%$ & $0.2 \%$ \\
\hline & \multirow[b]{2}{*}{ Construction } & Count & 25 & 0 & 0 & 25 \\
\hline & & $\%$ of total & $1.5 \%$ & $0.0 \%$ & $0.0 \%$ & $1.5 \%$ \\
\hline & \multirow{2}{*}{$\begin{array}{l}\text { Wholesale and retail trade; repair of motor } \\
\text { vehicles and motorcycles }\end{array}$} & Count & 479 & 4 & 76 & 559 \\
\hline & & $\%$ of total & $29.4 \%$ & $0.2 \%$ & $4.7 \%$ & $34.3 \%$ \\
\hline & \multirow{2}{*}{ Transportation and storage } & Count & 327 & 56 & 46 & 429 \\
\hline & & $\%$ of total & $20.1 \%$ & $3.4 \%$ & $2.8 \%$ & $26.3 \%$ \\
\hline & \multirow{2}{*}{ Accommodation and food service activities } & Count & 48 & 3 & 23 & 74 \\
\hline & & $\%$ of total & $2.9 \%$ & $0.2 \%$ & $1.4 \%$ & $4.5 \%$ \\
\hline & \multirow{2}{*}{ Information and communication } & Count & 8 & 1 & 0 & 9 \\
\hline & & $\%$ of total & $0.5 \%$ & $0.1 \%$ & $0.0 \%$ & $0.6 \%$ \\
\hline & \multirow{2}{*}{ Financial and insurance activities } & Count & 8 & 2 & 10 & 20 \\
\hline & & $\%$ of total & $0.5 \%$ & $0.1 \%$ & $0.6 \%$ & $1.2 \%$ \\
\hline & \multirow{2}{*}{ Real estate activities } & Count & 3 & 0 & 0 & 3 \\
\hline & & $\%$ of total & $0.2 \%$ & $0.0 \%$ & $0.0 \%$ & $0.2 \%$ \\
\hline & \multirow{2}{*}{ Professional, scientific and technical activities } & Count & 51 & 0 & 1 & 52 \\
\hline & & $\%$ of total & $3.1 \%$ & $0.0 \%$ & $0.1 \%$ & $3.2 \%$ \\
\hline & \multirow{2}{*}{ Administrative and support service activities } & Count & 44 & 18 & 0 & 62 \\
\hline & & $\%$ of total & $2.7 \%$ & $1.1 \%$ & $0.0 \%$ & $3.8 \%$ \\
\hline & \multirow{2}{*}{$\begin{array}{l}\text { Public administration and defence; compulsory } \\
\text { social security }\end{array}$} & Count & 0 & 1 & 0 & 1 \\
\hline & & $\%$ of total & $0.0 \%$ & $0.1 \%$ & $0.0 \%$ & $0.1 \%$ \\
\hline & \multirow{2}{*}{ Education } & Count & 19 & 0 & 0 & 19 \\
\hline & & $\%$ of total & $1.2 \%$ & $0.0 \%$ & $0.0 \%$ & $1.2 \%$ \\
\hline & \multirow{2}{*}{ Human health and social work activities } & Count & 11 & 0 & 0 & 11 \\
\hline & & $\%$ of total & $0.7 \%$ & $0.0 \%$ & $0.0 \%$ & $0.7 \%$ \\
\hline & \multirow[b]{2}{*}{ Arts, entertainment and recreation } & Count & 2 & 0 & 0 & 2 \\
\hline & & $\%$ of total & $0.1 \%$ & $0.0 \%$ & $0.0 \%$ & $0.1 \%$ \\
\hline & \multirow{2}{*}{ Other service activities } & Count & 10 & 0 & 0 & 10 \\
\hline & & $\%$ of total & $0.6 \%$ & $0.0 \%$ & $0.0 \%$ & $0.6 \%$ \\
\hline \multirow{2}{*}{\multicolumn{2}{|c|}{ Total }} & Count & 1387 & 86 & 156 & 1629 \\
\hline & & $\%$ of total & $85.1 \%$ & $5.3 \%$ & $9.6 \%$ & $100 \%$ \\
\hline
\end{tabular}

Source: Mokhele, 2016: 103

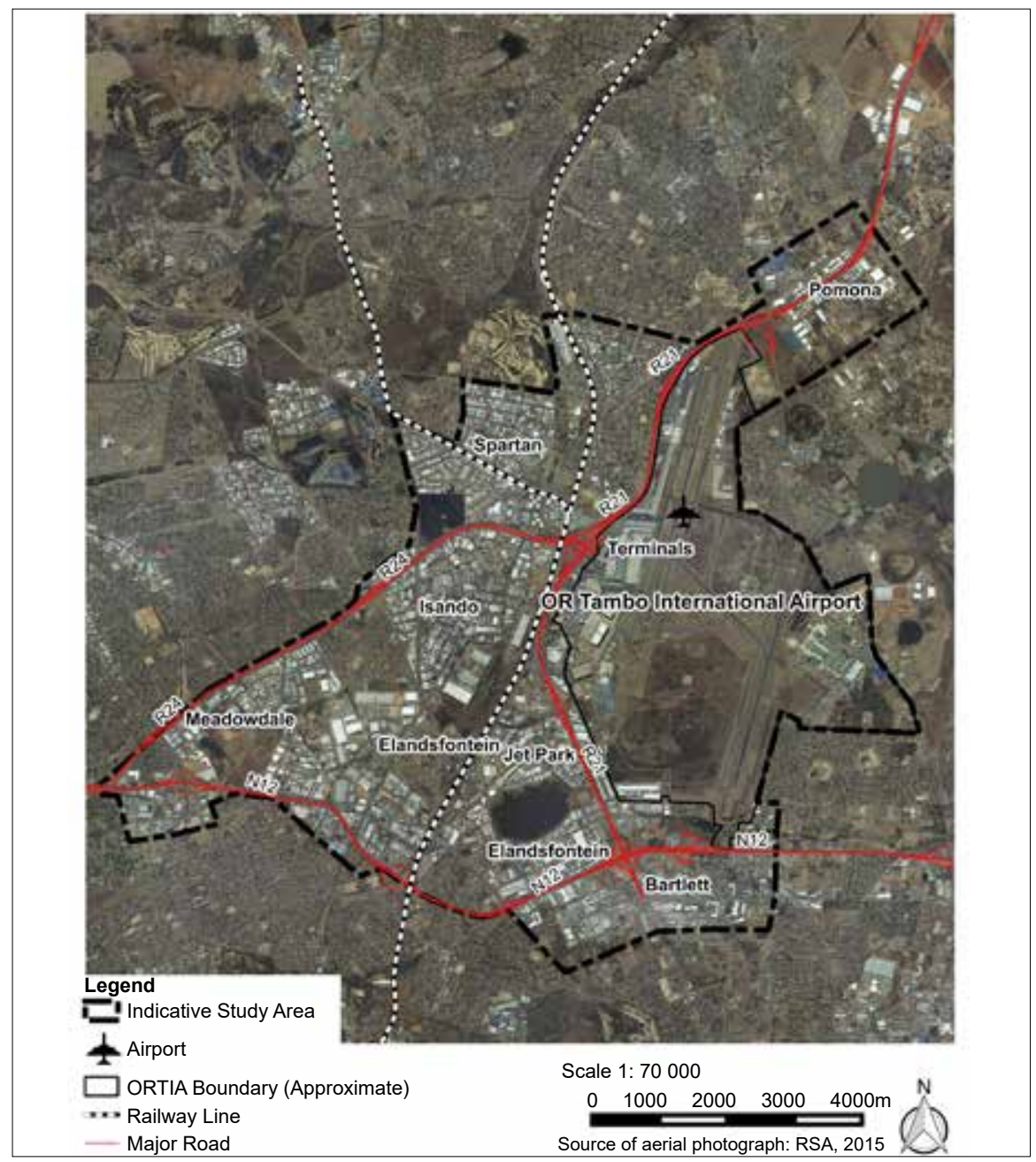

Figure 1: OR Tambo airport-centric development

Source: $\quad$ Adapted from Mokhele, 2016: 26
(Mokhele, 2016: 100) (see Table 2). Similar to ORTIA and surrounds, the Cape Town case studied is typically classified as an industrial area by the authorities, and considered to be one of the recognisable industrial nodes in the City of Cape Town municipality. Other concentrations of industrial activity (the majority of which are geographically larger than CTIA environs) are, among others, at the areas of Epping, Parow, Bellville, Brackenfell, Montague Gardens, Stikland, Blackheath, Paarden Eiland, Woodstock and Ottery.

\section{RESEARCH METHODOLOGY}

\subsection{Case study of Cape Town and OR Tambo airports}

This section provides a brief account on the rationale for the establishment of Cape Town and OR Tambo airports, including the criteria for selecting the location of the two airports. According to de Freitas (1968: 9), in 1943, the government of South Africa decided on the establishment of three international airports: one to the highest international standards and two to comparatively lower international standards. OR Tambo International Airport (ORTIA) was opened in 1953, known then as the Jan Smuts Airport, and was envisaged to be of the highest international standards in the country. ${ }^{2}$ The criteria for selecting its location (among other alternative sites) included good road and rail connections, particularly to the capital city, Pretoria (de Freitas, 1968: 13, 21).

Located in Ekurhuleni municipality, Gauteng province, ORTIA serves the Gauteng city-region, including the country's wealthiest city, Johannesburg, and the administrative capital city, Pretoria.

2 The name of OR Tambo International Airport (ORTIA) is used throughout the paper regardless of the timeframe under discussion. At the time of its opening, the airport was known as Jan Smuts Airport, named after the then South African Prime Minister, Jan Christiaan Smuts. The name was changed to Johannesburg International Airport in 1994, and in 2006, there was a renaming to the present name of ORTIA, named after Oliver Reginald Tambo, the former president of the African National Congress. 
Masilonyane Mokhele • Spatial economic evolution of the airport-centric developments of Cape Town ...

Cape Town International Airport (CTIA) was opened in 1954, known then as the DF Malan Airport. ${ }^{3}$ The airport was envisaged to be of lower international standard relative to ORTIA (de Freitas, 1968: 9). ${ }^{4}$ CTIA is located in the legislative capital city of Cape Town, Western Cape Province. As the main passenger airport in the province (with George Airport located over $400 \mathrm{~km}$ away), CTIA serves the country's second wealthiest city of Cape Town, and it is the gateway to the Cape Town functional region and the broader province.

\subsection{Research methods}

This article is based on a case-study approach, centred on the airportcentric developments of Cape Town and OR Tambo international airports (see Figures 2 and 3 in Section 3). Case-study approach is broadly defined as research in which analyses are undertaken on a phenomenon that is bounded by activity (Leedy \& Ormrod, 2010) wherein airport-centric development is a phenomenon defined by virtue of being located in the geographical proximity of airports. This attribute of proximity to airports made a casestudy approach appropriate towards addressing the aim of this article.

The two case studies were selected because, in comparison to other airports in South Africa, they accommodate substantial and diverse concentrations of economic activity, and thus serve as good platforms for analysing the spatial economic evolution of airport-centric developments.

In the case-study selection process, substantial concentration of economic activity was taken to refer to the physical extent of

3 At the time of its opening, Cape Town International Airport (CTIA) was known as the DF Malan Airport, named after the then South African Prime Minister, Daniel Francois Malan. The current name of CTIA was used from the 1990s following the inauguration of the country's first democratic government. Notwithstanding the period under discussion, the name of CTIA is used throughout the paper.

4 The other airport of lower international standards was established in Durban (de Freitas, 1968: 9): the then Durban International Airport, which was decommissioned in 2010 and replaced by King Shaka International Airport.
Table 2: Mix of Cape Town airport-centric development

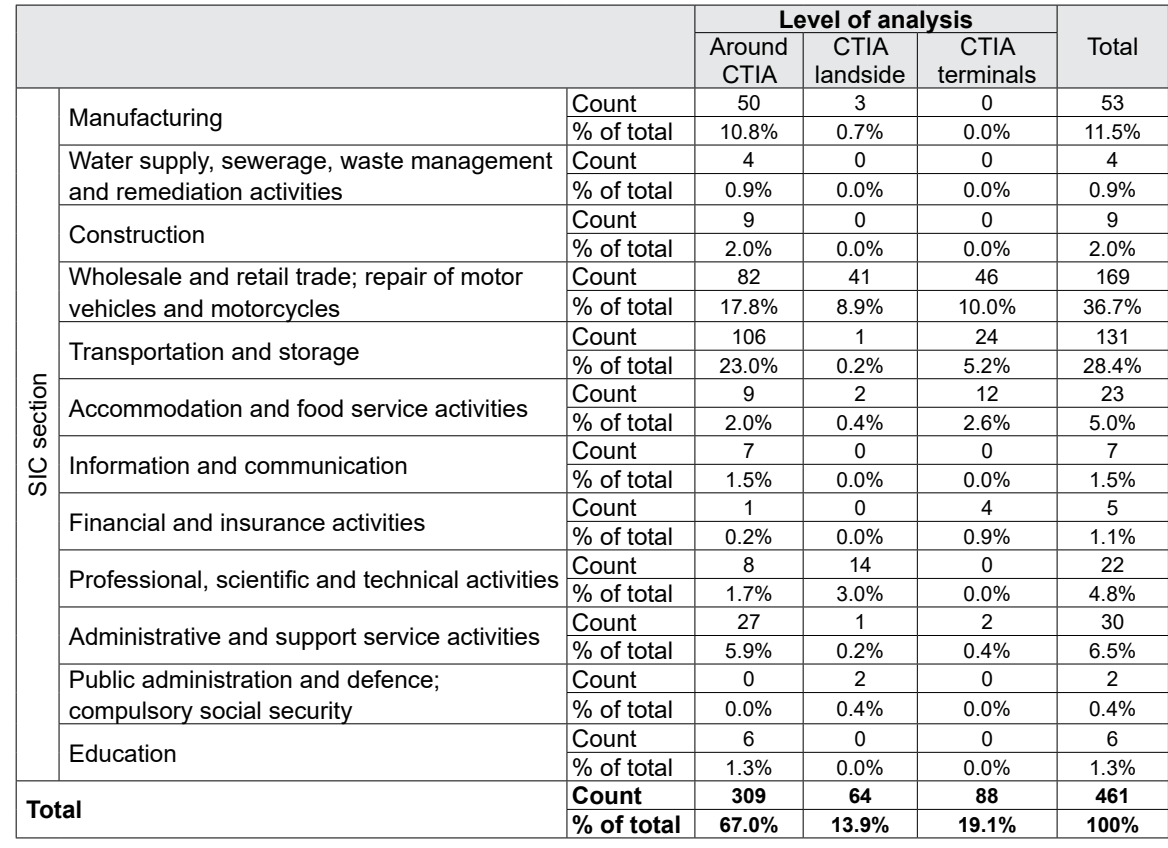

Source: Mokhele, 2016: 100

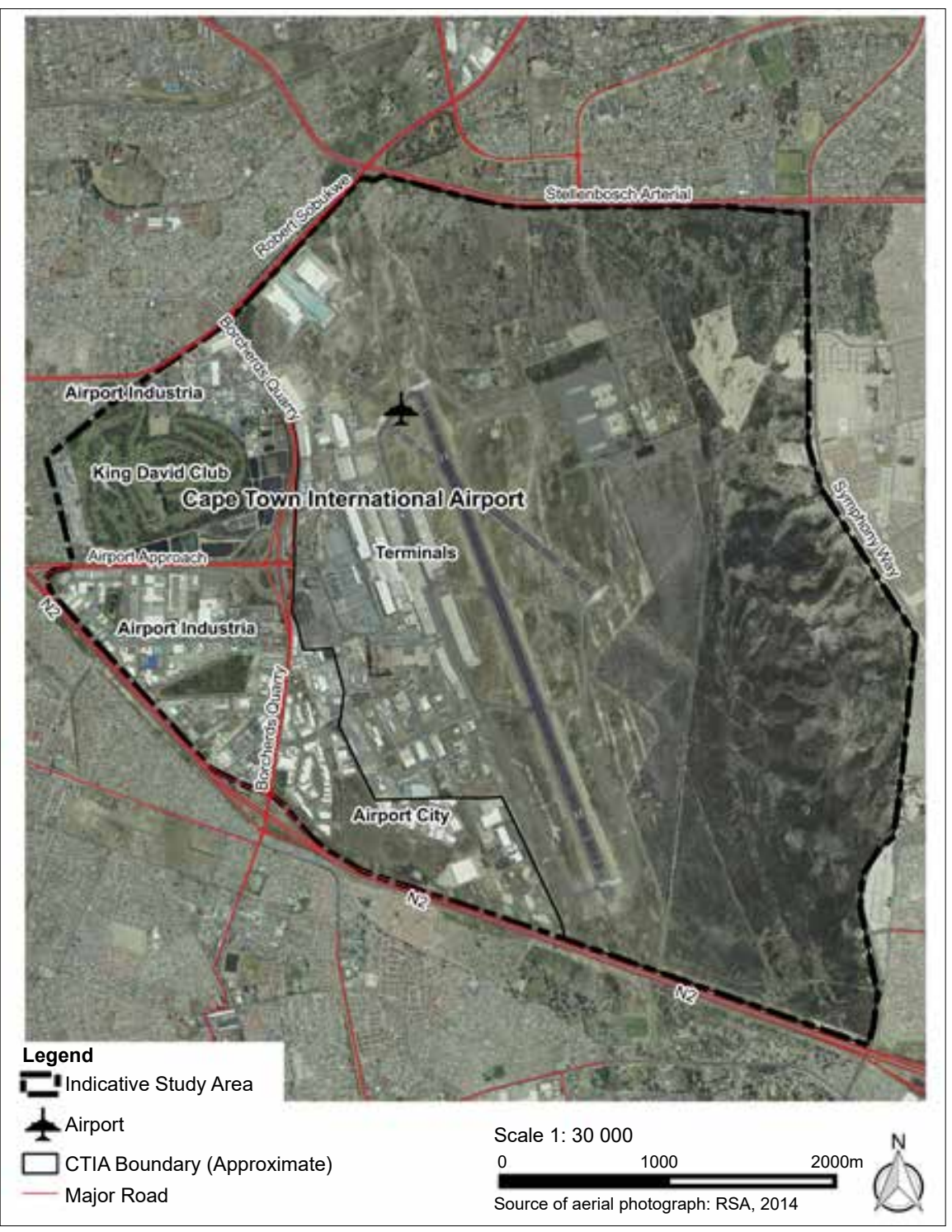

Figure 2: Cape Town airport-centric development

Source: $\quad$ Adapted from Mokhele, 2016: 27 
the airport-centric development, particularly on the landside and around the airports. It was, however, not possible to calculate the densities (number of firms per hectare, for instance) because of the lack of comprehensive information required for such calculations. Diversity was, in the case-study selection process, taken to refer to the existence of multiple land-use types on and around the airports, understood in contrast to a situation where only one land use exists or one land-use type dominates a composition. Diversity in the land-use composition of the cases studied was subsequently confirmed by the existence of firms in numerous SIC categories (refer to Section 3).

\subsection{Data collection}

After selecting the case studies, the following two sets of secondary information were sourced towards addressing the aim of the study. First, to trace the evolution of the spatial form of the airport-centric developments of CTIA and ORTIA, historical aerial photography and digital topographical maps (the latter at a scale of 1:50 000) were obtained from the national geospatial information. Secondly, the historical literature on the land-use composition of the cases studied was reviewed to supplement the aerial photography and topographical maps. Historical land use,

transportation and environmental information could, unfortunately, not be obtained from the City of Cape Town and Ekurhuleni municipalities. This was particularly due to the fact that the two municipalities previously comprised various municipalities, which were amalgamated into single municipalities after the year 2000. Hence, the municipal officials are not knowledgeable on the whereabouts of the historical information required.

Based upon the sets of information above, the evolution of the form of the airport-centric developments of CTIA and ORTIA was explored for six decades, namely the 1950s, 1960s, 1970s, 1980s, 1990s and 2000s. The adoption and usage of approximately 10-year difference was on the understanding that the timeframe is long enough to allow changes in the spatial form to be recognisable. Focusing on the aforementioned decades, the analysis of the spatial form focused specifically on economic activities of the airports and environs, as opposed to core aviation facilities such as runways and taxiways.

\subsection{Data analysis and interpretation of findings}

The aerial photography and topographical maps were loaded on the geographical information systems (GIS) computer program of Quantum GIS (QGIS), followed by a delineation of indicative study boundaries. Thereafter, an approach used to trace the evolution of the location of economic activities on the maps (that is, within the study boundaries) entailed identifying large buildings on the basis of the extent of land area covered by such buildings. On the aforementioned topographical maps, large buildings typically represent non-residential buildings, with community facilities specifically indicated with symbols such as $\mathrm{P}$ (for post office), PS (for police station) and $S$ (for school). Thus, large buildings with no symbols are understood to accommodate commercial activities. Other developed areas, such as predominantly residential areas, are noted as built-up areas (high, low density) and clearly distinguishable from the buildings noted above. ${ }^{5}$ Because the type of activities accommodated in the buildings cannot be identified on the maps, other written secondary sources of information (such as Cape Metropolitan Planning Committee 1980; CDE, 1997; City of Cape Town Municipality, 1983; 2002; Fair, 1956; Guide Plan Committee for the Cape Metropolitan Area, 1984; Rogerson, 1998; Schuman, 1975; Swanepoel, 2012; Van Zyl, 1981) were used to supplement the 1:50 000 topographical maps. The

\footnotetext{
5 Though it may appear speculative, this was the best approach given the lack of appropriate historical data. Also, given that the aerial photographs sourced were of poor quality (because they are scans of originals), the approach taken was better than relying solely on the photographs.
}

literature search was undertaken for two related reasons, namely to get a sense of the nature of activities at a particular period, and to uncover, in part, reasons that would have potentially influenced the location of activities and the change of spatial form of the cases studied.

\section{FINDINGS}

Informed by the research methods discussed in Section 4, the current section provides a snapshot of the evolution of the airport-centric developments of OR Tambo and Cape Town airports for the decades of 1950s, 1960s, 1970s, 1980s, 1990s and 2000s.

\subsection{OR Tambo and Cape Town airport-centric developments in 1950-1959}

When ORTIA opened in 1952, its environs were already endowed with high accessibility comprising, among others, the national road (N12), regional roads (R21 and $\mathrm{R} 24$ ) leading towards Pretoria to the north, and the Johannesburg/Pretoria-Germiston railway line. Two years after the opening of ORTIA, the airport environs did not have substantial urban development, although urban layouts (and associated road networks) existed west of the airport, at Isando and Spartan (see Figure 3).

As noted in Section 4, it is not sufficient to merely describe the spatial form at a given time, but it is equally important to explore potential reasons for the existence of that form, including the layouts at Isando and Spartan. Swanepoel (2012: 46) indicates that Isando was proclaimed as industrial township back in 1948 , and Isando extension 1 proclaimed in 1954. Possibly, the proclamations emanated from attempts by the government to promote the airport environs (and other selected areas of the municipality) as industrial areas.

Fair (1956: 22) explains that, in certain areas of the then East Rand (now Ekurhuleni municipality), there was a shortage of land proclaimed for industrial development. Because of the government's concern with the anticipated decline and demise 
of the mining industry, there was a need to identify a secondary industry to replace mining as a driver of the economy. As a result, from before 1948, local authorities, in a way competing with each other, introduced various inducements to attract industrial development to their areas (Fair, 1956: 25).

In Cape Town, when CTIA opened in 1954, it was situated in an accessible area bounded to the south by the freeway (N2), leading towards Cape Town CBD located

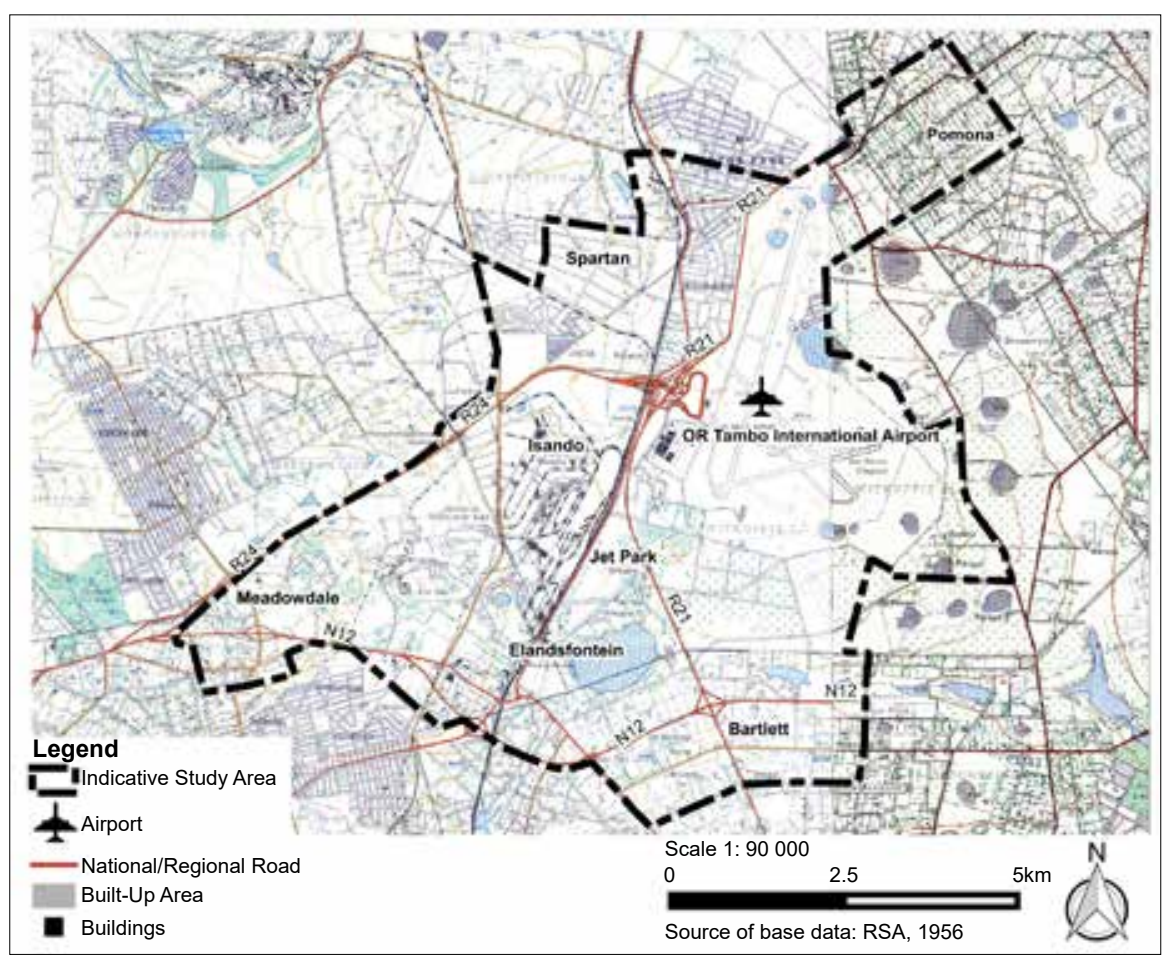

Figure 3: OR Tambo International Airport and surrounds in 1954

Source: $\quad$ Adapted from Mokhele, 2016: 130

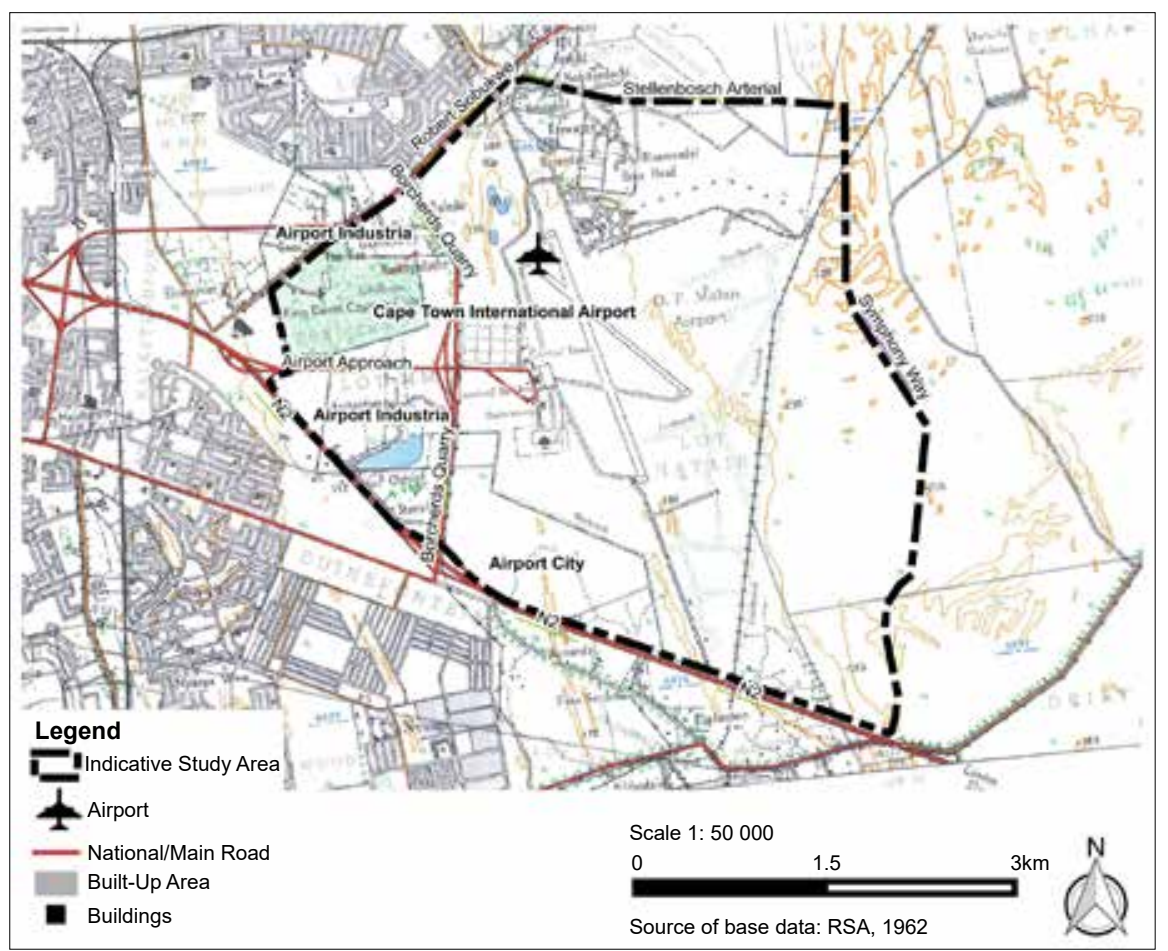

Figure 4: Cape Town International Airport and surrounds in 1958

Source: $\quad$ Adapted from Mokhele, 2016: 131 approximately $18 \mathrm{~km}$ to the west. However, unlike the ORTIA case studied, the environs of CTIA did not (and still do not) have access to a railway system. Figure 4 shows CTIA and surrounds in 1958, about four years after the opening of the airport. At the time, there was no sign of urban development at the environs of CTIA, as the airport itself was established on a farmland.

\subsection{OR Tambo and Cape Town airport-centric developments in 1960-1969}

In 1961, about nine years after the opening of the airport, the area around ORTIA was still predominantly agricultural and characterised by sparse urban activities. The area to the west (Isando) accommodated agricultural smallholdings in transition towards urban development. CDE (1997: 11) notes that, particularly in the early $1960 \mathrm{~s}$, municipalities in the former East Rand continued to promote industrial development by rezoning unused mining and agricultural land, and establishing infrastructure and services for industrial townships. That land, typically situated along main roads and railway lines, was then sold to developers at cheap prices. In this way, the government continued on a business strategy to attract industrial activity for the economy to be sustainable in case gold mining faltered (CDE, 1997: 11).

As regards Cape Town, in 1966, when CTIA had been operational for about 12 years, the area around the airport was still undeveloped.

\subsection{OR Tambo and Cape Town airport-centric developments in 1970-1979}

In 1975, Isando had transformed considerably to accommodate a substantial concentration of industrial activities. The proclamation of Isando as industrial township and the proclamation of Isando extensions (see Swanepoel, 2012: 46) would have allowed the increasing physical extent of industrial development visible in Figure 5. A concentration of economic activities had also emerged at Elandsfontein, to the south-west of ORTIA. CDE (1997: 11) indicates 
that, around that time, there was a new concentration of firms particularly involved in storage, transport, communications and wholesaling along the railway lines, freeways, and close to ORTIA, among other areas. The case studied would have been particularly advantaged in this regard, given that it has access to the railway line and the N12 Freeway. Despite these changes in the concentration of activities, Meadowdale was largely undeveloped, and the urban development in Jet Park was still sparse.

While the OR Tambo airport-centric development was developing at a relatively quick pace, the emergence of development on and around CTIA was slow. A mapping exercise undertaken by Schuman (1975), pertaining to the extent of urban development in the broader Cape Town, reflects that the environs of CTIA did not accommodate any urban development in 1974. As shown in Figure 6, towards the end of the decade in 1979, the area around CTIA was still largely undeveloped (see Cape Metropolitan Planning Committee, 1980).

\subsection{OR Tambo and Cape Town airport-centric developments in 1980-1989}

In 1983, there was further establishment of economic activities in Jet Park and Elandsfontein, to the south-west of ORTIA. The aforementioned areas, with Spartan and Isando, had transformed significantly to accommodate industrial activities. According to CDE (1997: 20), the decade of the 1980s was marked by a significant shift of industrial activities from the traditional manufacturing areas toward locations with freeway access close to ORTIA. As a result of that shift in demand, rentals of industrial premises increased in Isando and new industrial properties were developed in Jet Park (CDE, 1997: 20).

In Cape Town, in the 1970s and 1980s, the government was vigorously trying to promote industrial activity in the vicinity of CTIA. In 1981, approximately 130 hectares of land at Borcherds Quarry (now Airport

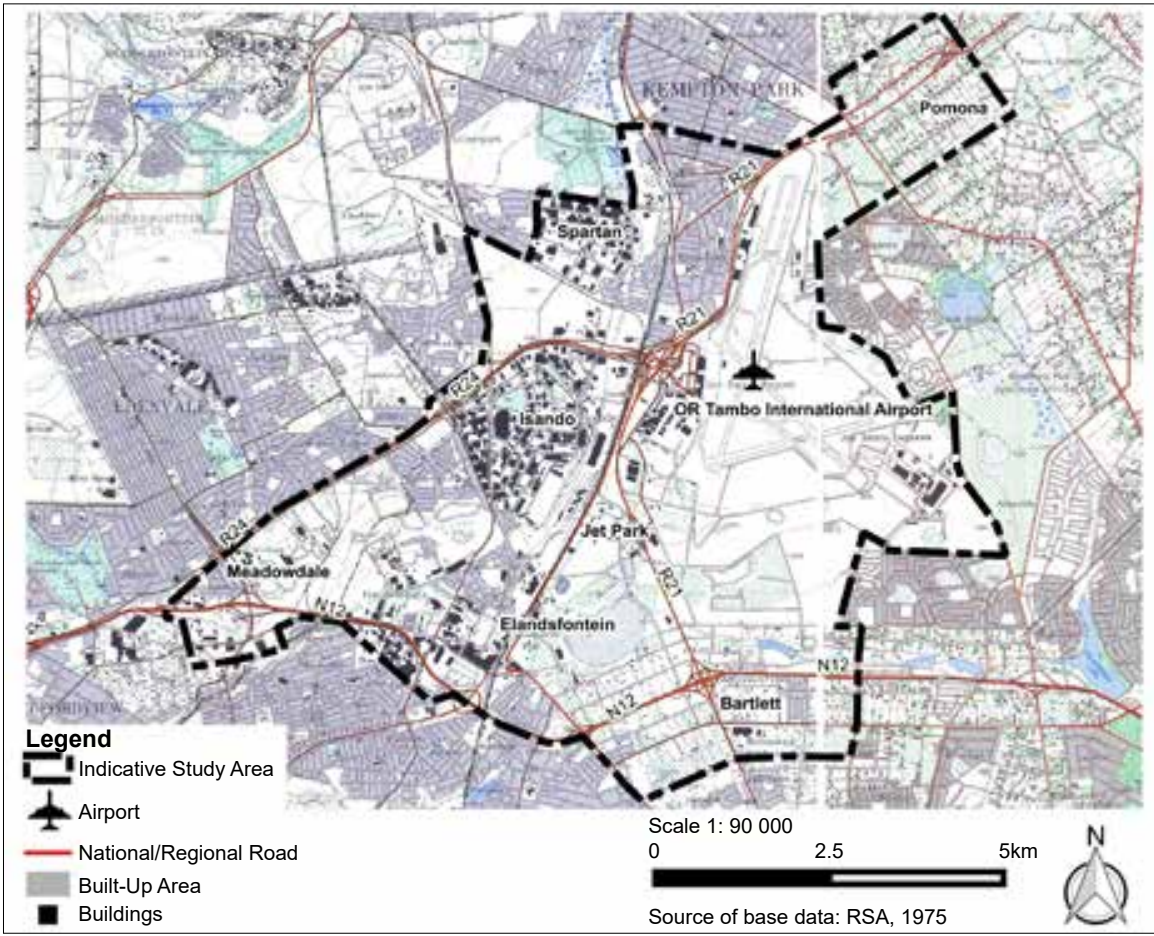

Figure 5: OR Tambo International Airport and surrounds in 1975

Source: $\quad$ Adapted from Mokhele, 2016: 134

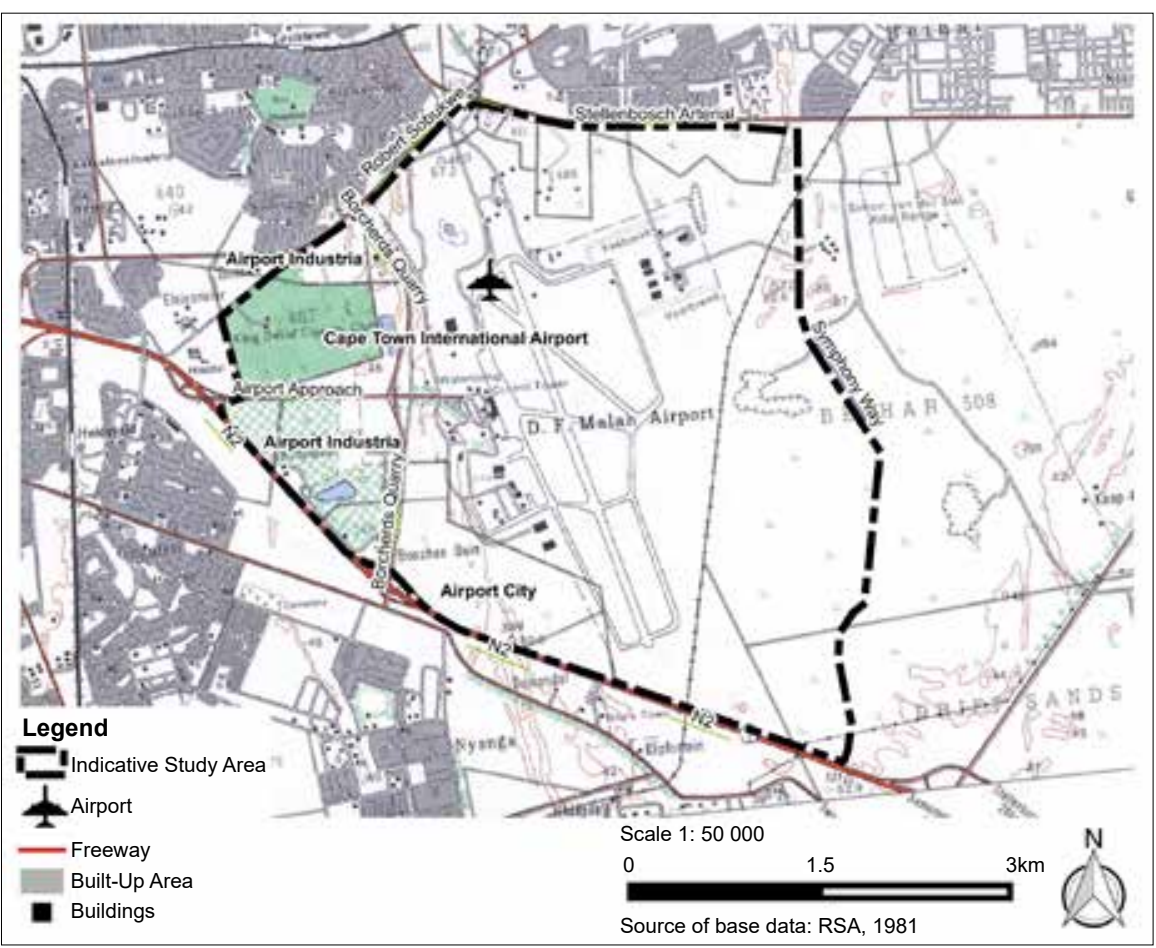

Figure 6: Cape Town International Airport and surrounds in 1979

Source: $\quad$ Adapted from Mokhele, 2016: 135

Industria) were zoned for industrial purposes (City of Cape Town Municipality, 1983), and the majority (79 hectares) of that land was not occupied (Van Zyl, 1981), potentially due to low demand for industrial land at the airport environs. The zoning of the area was consistent with the City's spatial planning policy, the
Cape Metropolitan Area Guide Plan (1984), which designated Borcherds Quarry for industrial purposes (Guide Plan Committee for the Cape Metropolitan Area, 1984).

However, despite the attempts to promote industrial development, the spatial form of the environs of CTIA 


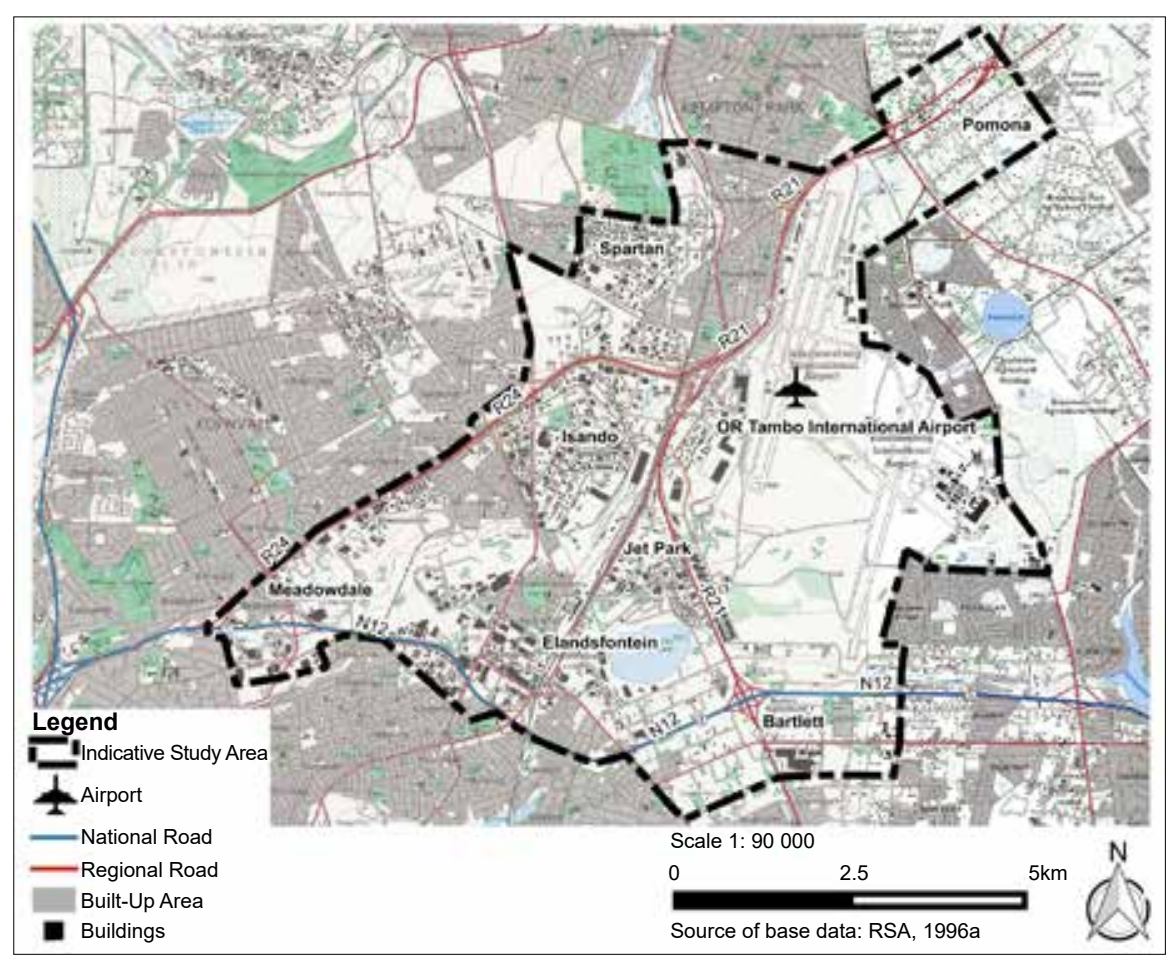

Figure 7: OR Tambo International Airport and surrounds in 1995

Source: $\quad$ Adapted from Mokhele, 2016: 138

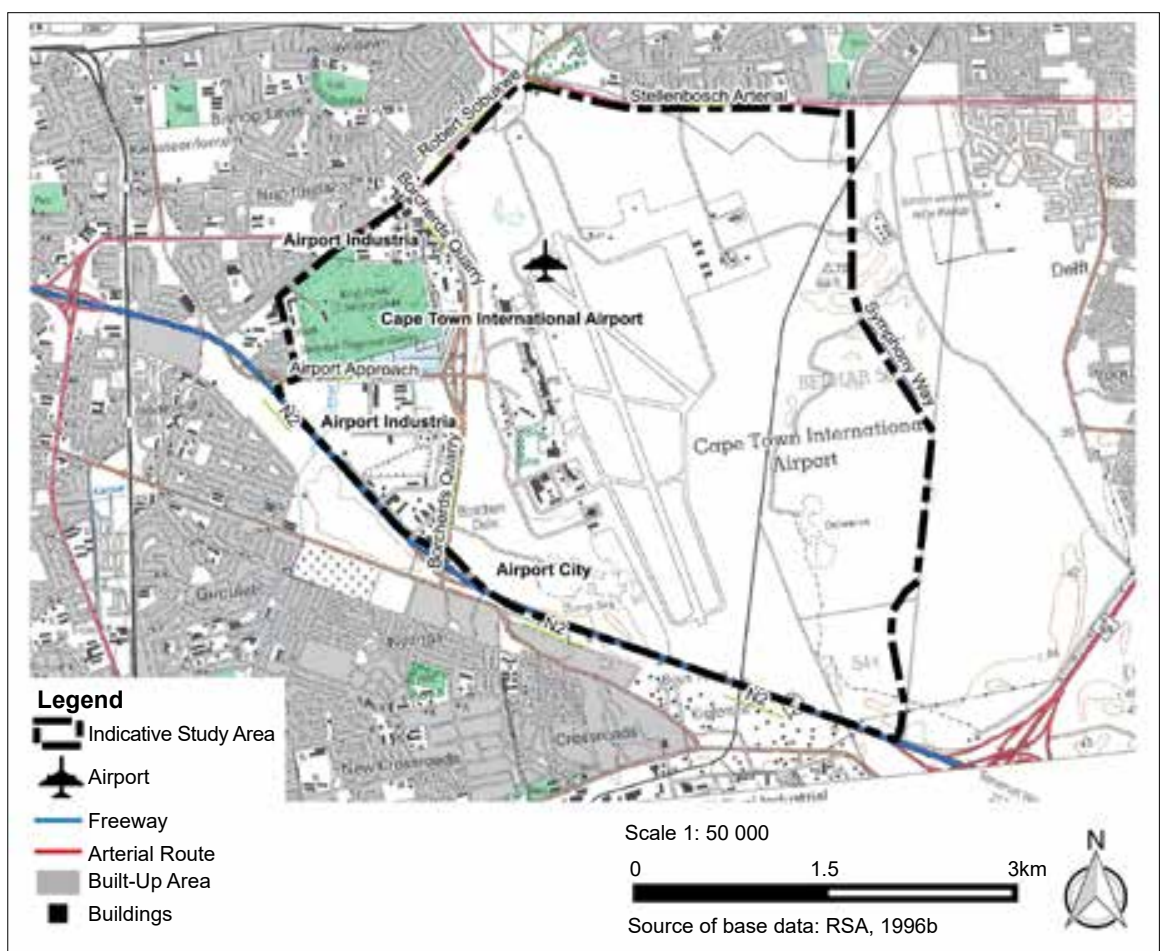

Figure 8: Cape Town International Airport and surrounds in 1993

Source: $\quad$ Adapted from Mokhele, 2016: 139

had not changed much in 1983 , about 29 years after the opening of the airport.

\subsection{OR Tambo and Cape Town airport-centric developments in 1990-1999}

In Ekurhuleni, as anticipated, the 1990s experienced a decline in mining and a shift from the natural resource-based industrial development (Rogerson, 2006: 124).
In the same decade, according to CDE (1997: 14), new just-in-time distribution methods resulted in the creation of a distribution hub for logistics companies around ORTIA, including the construction of new warehousing facilities for manufacturing and retail companies. Mainly using the 1989 and 1994 industrial registers, Rogerson (1998) examined factors that promote the emergence of high-technology manufacturing clusters around ORTIA and Midrand. The study discovered access to ORTIA to be a major factor that influenced the location of hightechnology manufacturing firms in the vicinity of the airport, particularly for airfreight services. In 1995, Jet Park was largely developed, in addition to the areas of Isando, Spartan and Elandsfontein. Around that time, establishments were beginning to emerge at Meadowdale, to the far south-west of ORTIA. A further change in the form of ORTIA and surrounds was also brought about by the cropping up of activities to the east of the airport premises (Figure 7).

In 1993, as regards the Cape Town airport-centric development, a trend could be identified of a new, but still small growth in warehousing and storage facilities close to CTIA (City of Cape Town Municipality, 2002). As shown in Figure 8, the form of the environs of CTIA had changed considerably from the previous decade, particularly with more activities concentrating to the west of the airport, at Airport Industria. Around the time, the airport authority (Airports Company South Africa) also started to enable the landside to attract investment from industrial, freight and warehousing firms (City of Cape Town Municipality, 2002).

\subsection{OR Tambo and Cape Town airport-centric developments in 2000-2009}

Figure 9 shows the environs of ORTIA in 2002. At that time, the development had extended to Bartlett, an area to the south of the airport, and Meadowdale was continuing to accommodate more urban activities. The spatial form of the airport-centric development 
was at the time largely similar to the current context (see Figure 1 in Section 3). As regards further attempts to attract industrial activities on and around ORTIA, an industrial development zone (IDZ), known then as the Johannesburg International Airport IDZ (comprising a land area of 726 hectares), was designated in 2003 (see RSA, 2002). ${ }^{6}$

At CTIA and surrounds, a significant part of Airport Industria's land area

6 Johannesburg IDZ was one of the four Industrial Development Zones designated in the country between 2001 and 2010 (Nel \& Rogerson, 2013), and the only one situated inland.

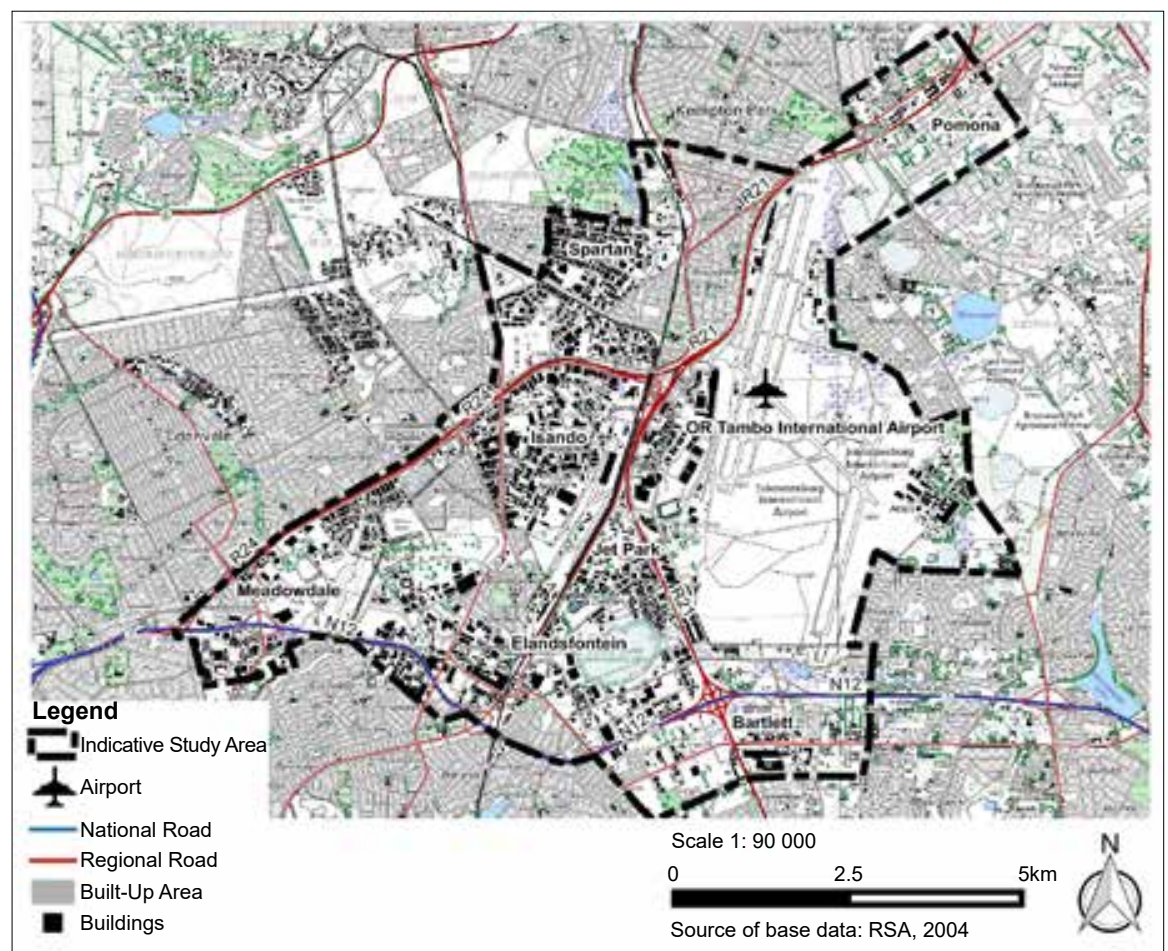

Figure 9: OR Tambo International Airport and surrounds in 2002 Source: $\quad$ Adapted from Mokhele, 2016: 140

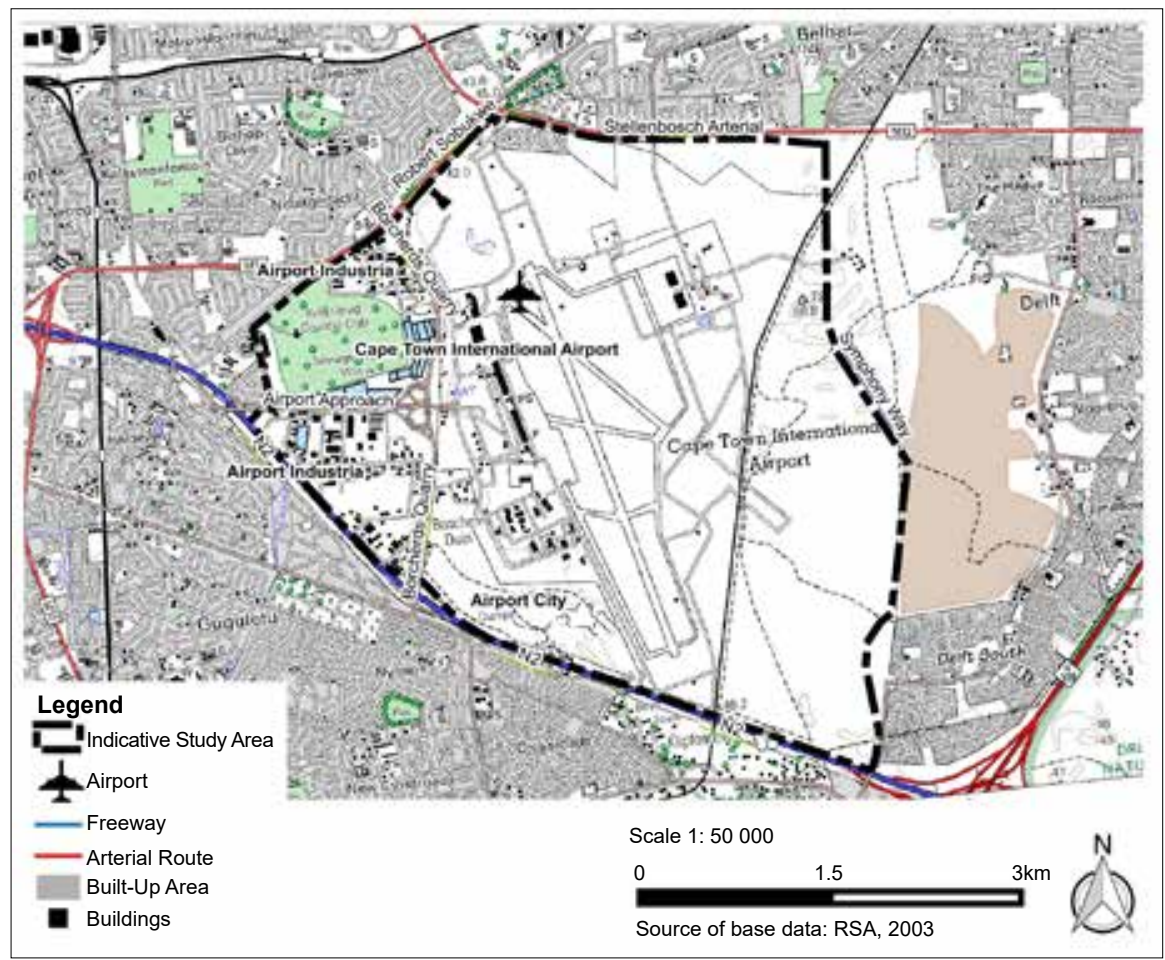

Figure 10: Cape Town International Airport and surrounds in 2000

Source: $\quad$ Adapted from Mokhele, 2016: 141 was developed in 2000. At a wider municipal area, Cape Town City Council (1992) notes that Montague Gardens had been the fastest growing industrial area since 1985 and other areas, including Airport Industria, had also grown over the same period.

It is important to observe that, at the time, besides Airport City, which was not yet established to the south of CTIA (see Figure 10), the spatial form was largely similar to the current context (refer to Figure 2 in Section 3).

\section{CONCLUSION}

The aim of this article was to analyse the evolution of the spatial form of the environs of Cape Town and OR Tambo international airports in South Africa. The criteria for selecting the location of the two airports (within Cape Town and Gauteng, respectively) included the accessibility of the locations through road- and/or rail-based modes of transport. When the two airports were subsequently established at the highly accessible locations, the environs did not accommodate urban development, as the airports were themselves established on farmlands.

Following the various efforts by the respective municipalities to attract industrial development at the airport environs (including rezoning and/ or servicing of the land in line with planning documents), the OR Tambo airport-centric development emerged significantly in the 1970s, while the spatial form of the environs of Cape Town Airport changed significantly only in the early 1990s. The aforementioned initiatives emanated from changes in the drivers of the economy at the municipal, provincial and national levels. This was particularly evident in the case of Gauteng province wherein manufacturing was identified as a potential driver of the economy in light of the anticipated decline of gold mining. In the 2000s, the spatial form of the cases studied was largely similar to the current context as regards the land area covered by development. 
To at least in part inform the planning of other airports and surrounds, the following interrelated lessons are, therefore, drawn from the paper:

- The development of airport environs occurs over long time frames.

- Planning of airports and surrounds should not be considered in isolation of other planning initiatives at the municipal, provincial and national levels.

- The success of the implementation of development on and around airports may be influenced by the intra- and intermetropolitan accessibility of the airport environs through different modes of transport.

In light of these lessons, it is imperative that the planning of airport-centric developments be informed by the integration of spatial, economic, and transportation planning, as well as institutional and environmental considerations at different scales.

\section{ACKNOWLEDGEMENTS}

Financial support of the National Research Foundation (NRF) towards this study is acknowledged. Opinions and conclusions arrived at are those of the author and are not necessarily to be attributed to the NRF.

\section{REFERENCES LIST}

AIRPORTS COMPANY SOUTH AFRICA (ACSA). 2015. Airports Company South Africa Integrated Report 2015. Bedfordview: ACSA. [online]. Available from: http://www. airports.co.za/FinancialResults/ ACSA\%20IR\%202015.pdf [Accessed: 7 December 2015].

BLANTON, W. 2004. On the airfront. Planning, 70(5), pp. 34-35.

BROUMELS, M. (Ed.). 2014. The local government handbook: South Africa 2014. $4^{\text {th }}$ edition. Cape Town: Yes Media.

CAPE METROPOLITAN PLANNING COMMITTEE. 1980. Manufacturing employment in the Cape metropolitan area: An analysis of employment in the manufacturing industries of the Cape metropolitan area during 1976-1977.
CAPE TOWN CITY COUNCIL. 1992.

Towards a draft metropolitan spatial development framework. Notes from a work: December 7/8, 1992. Cape Town: Town Planning Branch.

CENTRE FOR DEVELOPMENT AND ENTERPRISE (CDE). 1997. The East Rand: Can South Africa's workshop be revived? CDE Research. Policy in the making. The big cities series. CDE Research No. 5, June. Johannesburg: Centre for Development and Enterprise.

CITY OF CAPE TOWN MUNICIPALITY. 1983. Cape Town metropolitan transport area: People, employment and land in the eighties. Cape Town: City of Cape Town.

CITY OF CAPE TOWN MUNICIPALITY. 2002. MSDF review/New city SDF. Phase 1: Spatial analysis, trends and implications. Cape Town: City of Cape Town Municipality.

CONWAY, M. 1993. Airport cities 21: The new global transport centers of the $21^{\text {st }}$ century. Atlanta GA: Conway Data.

DE FREITAS, F. 1968. Airports of South Africa. Johannesburg: Da Gama.

EICKER, K. 2009. Cradle City's promising design: Precedent for sustainability. Urban Green File, 14(3), pp. 20-25.

EKURHULENI MUNICIPALITY. 2013. Ekurhuleni aerotropolis planning and land use guidance document. Ekurhuleni:

Ekurhuleni Metropolitan Council.

EKURHULENI MUNICIPALITY. 2015.

Ekurhuleni 25 year aerotropolis master plan: Part 6: Land use plan. Ekurhuleni: City of Ekurhuleni. [online]. Available from: http://www.ekurhuleni.gov. za/2626-aerotropolis-master-plan/file [Accessed: 18 January 2016].

FAIR, T.J.D. 1956. A planning survey of the Southern Transvaal: The PretoriaWitwatersrand-Vereeniging area. Pretoria: Government Printer.

FREESTONE, R. \& BAKER, D. 2011. Spatial planning models of airport-driven urban development. Journal of Planning Literature, 26(3), pp. 263-279. https://doi. org/10.1177/0885412211401341

GUIDE PLAN COMMITTEE FOR THE CAPE METROPOLITAN AREA. 1984. Cape metropolitan area draft guide plan. Volume 1. Cape Town: Guide Plan Committee.
KASARDA, J.D. 1998. The global transpark: Infrastructure for industrial advantages. Urban Land, 57(4), pp. 107-110.

KASARDA, J.D. 2009. Airport cities. Urban Land, 68(4), pp. 56-60.

KASARDA, J.D. \& LINDSAY, G. 2011. Aerotropolis: The way we'll live next. London: Penguin Group.

KLUG, N., RUBIN, M. \& TODES, A. 2014. The north-western edge. In: Harrison, P. Gotz, G., Todes, A. \& Wray, C. (Eds). Changing space, changing city: Johannesburg after apartheid. Johannesburg: Wits University Press, pp. 418-436.

LEEDY, P.D. \& ORMROD, J.E. 2010.

Practical research: Planning and design. $9^{\text {th }}$ edition. Upper Saddle River, NJ: Pearson.

MEIER, R.L. 1974. Planning for an urban world. Cambridge, MA: The Massachusetts Institute of Technology Press.

MOKHELE, M. 2016. Spatial economic attributes of airportcentric developments in Cape Town and Johannesburg. Unpublished thesis (PhD). Stellenbosch:

Stellenbosch University.

NEL, E.L. \& ROGERSON, C.M. 2013. Special economic zones in South Africa: Reflections from international debates. Urban Forum 24(2), pp. 205-217.

REPUBLIC OF SOUTH AFRICA (RSA). 2002. Consideration of an area as an industrial development zone (IDZ): Johannesburg International Airport (JIA) IDZ. Notice No. 152 (Department of Trade and Industry). Government Gazette Volume 440, No. 23084. Pretoria: Government Printer. [online]. Available from: http://www.gov.za/ sites/www.gov.za/files/23084_0.pdf [Accessed: 4 July 2015].

ROGERSON, C.M. 1998. Hightechnology clusters and infrastructure development: International and South African experiences. Development Southern Africa 15(5), pp. 875-905. https://doi. org/10.1080/03768359808440054

ROGERSON, C.M. 2006. From national industrial workshop to 'rustbelt'? Restructuring the manufacturing economy of Ekurhuleni, 1980-1999. In: Simon, R. (Ed.). Sustainable manufacturing? The case of South Africa and Ekurhuleni. Cape Town: Juta, pp. 112-120. 
SCHLAACK, J. 2010. Defining the Airea. Evaluating urban output and forms of interaction between airport and region. In: Knippernberger, U. \& Wall, A. (Eds). Airports in cities and regions: Research and practice. Proceedings of the $1^{\text {st }}$ international Colloquium on Airports and Spatial Development held on 9-10 July 2009, pp. 113-125.

SCHUMAN, C.W.E. 1975. A guide plan for the growth of metropolitan Cape Town. Maps-Figures-Diagrams. University of Cape Town, Department of Urban \& Regional Planning.

SIT, V. 2004. Global transpark: New competitiveness for Hong Kong and South China based on air logistics. Geografiska Annaler. Series B, Human Geography, 86(3), pp. 145-163. https://doi. org/10.1111/j.0435-3684.2004.00159.x

STATISTICS SOUTH AFRICA. 2012. Standard industrial classification of all economic activities (SIC). $7^{\text {th }}$ edition. Pretoria: Statistics South Africa.

SWANEPOEL, P.A. 2012. The land development impact of OR Tambo International Airport on surrounding industrial areas. Master's minidissertation. Pretoria: University of Pretoria, Department of Town and Regional Planning.

VAN ZYL, G.N. 1981. The location of manufacturing industry in the metropolitan area 'Die vestiging van vervaardigingsbedrywe in die Kaapse Metropolitaanse gebied.' Proceedings of the Planning in the Cape Metropolitan area. Transport, land use, housing and other important issues. The South African Institute of Town and Regional Planners.

WALKER, A.R. \& STEVENS, N.J. 2008. Airport city development in Australia: Land use classification and analyses. Proceedings of the $10^{\text {th }}$ TRAIL Congress and Knowledge Market held on 14-15 October 2008, Rotterdam, The Netherlands. 